\title{
Ecosystem services of natural floodplain segment - Lužnice River, Czech Republic
}

\author{
D. Pithart ${ }^{1}$, K. Křováková ${ }^{1}$, J. Žaloudík ${ }^{2}$, T. Dostál ${ }^{3}$, J. Valentová $^{3}$, \\ P. Valenta ${ }^{3}$, J. Weyskrabová ${ }^{3}$ \& J. Dušek ${ }^{1}$ \\ ${ }^{1}$ Institute of Systems Biology and Ecology, ASCR, Czech Republic \\ ${ }^{2}$ Biology Centre of the ASCR, Institute of Hydrobiology, Czech Republic \\ ${ }^{3}$ Faculty of Civil Engineering, Czech Technical University in Prague, \\ Czech Republic
}

\begin{abstract}
The river Lužnice floodplain in south Bohemia with a preserved floodplain ecosystem and hydrological regime has been investigated for selected ecosystem services (ES): flood mitigation, biodiversity refuge, carbon sequestration, and production of commodities. Two contrasting scenarios at $5 \mathrm{~km}$ long studying floodplain segment were compared: near-nature state as it is (Scenario A) and virtually transformed floodplain (Scenario B). For the flood mitigation service, we used an output from hydraulic analysis of modelled flood events (model FAST 2D) showing the effective retention volume $2.3 \mathrm{mil} \mathrm{m}^{3}$ for A and $0.83 \mathrm{~m}^{3}$ for B. For monetary evaluation, we used the method of replacement cost of this retention volume. For biodiversity refuge, the value of biotopes (real for A and arbitrary for B) and their contribution to the floodplain area were analysed according to the Hessen method. Carbon sequestration was measured by eddy-covariance method. All ES for both scenarios were converted to monetary value and scenarios A and B were compared. The contribution of particular ES to the total ecosystem value showed the importance of flood mitigation and biodiversity refugium compared to other services. Overall floodplain value was estimated as 17213 EUR ha. ${ }^{-1} \cdot \mathrm{yr}^{-1}$ for state as it is (A) and 6254 EUR ha. ${ }^{-1} \cdot \mathrm{yr}^{-1}$ for transformed floodplain (B), i.e. virtual floodplain transformation decreased its value to $36 \%$.
\end{abstract}

Keywords: floodplain, ecosystem services, monetary evaluation flood mitigation, carbon sequestration, biodiversity. 


\section{Introduction}

In 2005, Czech water management authorities accomplished a long-term strategic plan for the subsequent decade called "Plan of main watersheds" (PMW [1]). This plan has reflected the expected climate change scenarios, predicting lower precipitation in summer periods and higher frequency of extreme hydrological events. As the main tool to tackle this future situation, the plan proposed land reservations for 206 new water reservoirs, some of them of substantial capacity. Even if this proposal did not actually mean the final decision to build these constructions, it has understandingly alarmed residents of the affected areas, environmental NGO's, and scientific community as well. As a result of their campaign and lobbying, the appendix with the list of these land reservations was removed from the PMW; its new version, finally approved by the government, adopted more "soft" or environmentally sensitive measures to increase water retention in the landscape.

During this both public and expert debate environmentalists and ecologists pleaded for integration of natural ecosystems benefits and services into the national strategy of water management. But in the course of this discussion debaters were increasingly aware of our inability to quantify properly retention effect of nature ecosystems, moreover to evaluate their other various benefits, not directly connected to water management range of responsibilities. Hence the river revitalizations, based on re-meandering and decrease of discharge capacity is still perceived by most of water managers as an enterprise beneficial for the environment, but not as a tool helping to fulfil their own tasks - for such a purpose the hard engineering structures are still recognized as more reliable and effective.

Among the "soft" measures, the use of river floodplains was broadly discussed, because of their natural potential to mitigate extreme hydrological events. However, most of floodplains in Europe have lost their retention capacity due to the massive river regulation - for what canalisation of river beds and construction of levees are the typical structures. Consequent change of land use into the arable land and/or even settlements made the use of floodplain as a flood wave buffer zone practically impossible. However, nowadays the situation is changing: increase of extreme floods made the floodplain settlement and intensive agriculture disputable and also the demand for agriculture production have decreased. Hence, the crucial question appeared: Should we re-consider the role of floodplain in the landscape? Can we revitalize its original functions? Would it be more beneficial to reverse some floodplains into the near-natural state? Even if environmentalists would give a positive answer to this question, it is not easy to persuade the rest of the society - with water management authorities in the front line. Not to mention generation or political aspects of the problem, very soon we come to the situation when we feel the lack of data and quantification to compare natural and transformed river floodplains in terms of their functions and benefits. How to balance, for instance, such functions as different as biodiversity and flood mitigation? 
The concept of ecosystem services (Turner et al. [2]) may bring some progress in this argumentation, enabling to evaluate and add together various ecosystem benefits, which had not been countable in principle. Theoretically, wetland services such as flood mitigation, groundwater recharge, biodiversity and commercial hunting can be expressed in their monetary values, added together and used for more holistic wetland valuation and/or in decision-making process. Even if the monetary evaluation can be tentative or ranging in a wide interval, such process is innovative and mind provoking; because it helps us to understand nature values which were traditionally taken for granted or were not recognized at all.

The aim of this study is to compare selected ecosystem services - those, for which we were able to gain the key data, i.e. flood mitigation, maintenance of biodiversity, carbon sequestration and production (fish, hay, timber and wheat) at two contrasting scenarios of the Lužnice river floodplain - state as it is, which is near-natural state - and a virtual state of massive transformation. Ecosystem services were expressed in their monetary values, converted to area; and added together for both scenarios in order to balance their overall benefit.

\section{Locality}

The Lužnice floodplain area is located in the south of the Czech Republic between the Austrian border and the town Suchdol nad Lužnicí. The preserved part of the floodplain is about $15 \mathrm{~km}$ long and $1-2 \mathrm{~km}$ wide. It is one of the few floodplains in the Czech Republic where natural hydrological regime had not been altered substantially by any massive river regulation. The riverbed meanders and changes its course after any major flood event. This part of floodplain is flooded for several weeks every year, mostly in March and April, with occasional floods in winter or summer. The long term (50 years) average river discharge is $5.8 \mathrm{~m}^{3} \mathrm{~s}^{-1}$. The floodplain area consists of main stream and standing water bodies (4\% of the area, 200 permanent pools and oxbows, Pithart et al. [3]), meadows both maintained and abandoned (the latter prevailing, mainly overgrown by Phalaris arundinacea and Urtica dioica), pastures, and floodplain softwood and hardwood forest (18\%, dominated by willows and white poplars with admixed oaks and alders). In winter, the water bodies regularly freeze over and ice is mostly covered by snow. The water level fluctuates in the range of $1.5 \mathrm{~m}$. There is no settlement within the floodplain. Hence, the system is fully adapted to periodical flooding including its agricultural and social level. The area we used for this study is a $5 \mathrm{~km}$ long segment (area $283.5 \mathrm{ha}$ ) between the border with Austria and the bridge at Halámky village.

Carbon sequestration was measured at Mokré louky wetland site, a flat depression with an area of 450 ha. The area is covered by up to several meters thick layer of peat, which is superimposed on quarternary alluvial sands and clays. The site is situated in the inundation area of a large human-made lake (Rožmberk fishpond, $5 \mathrm{~km}^{2}$ ), flown through Lužnice river. The water level is controlled by a system of ditches, which interconnect the man-made lakes 
(fishponds) in the whole region and is thus fairly stable throughout the year. The meteorological and eddy covariance station are situated in the wettest part where water level is kept at -0.2 to $0.1 \mathrm{~m}$. Spring or summer floods occur irregularly as a consequence of snow melting or summer rains. Vegetation of the site is affected by regular mowing and occasional manuring with organic material and by sewage water from a pig-farm. Among the plants dominating the wetland are short and tall sedge marshes (Caricion fuscae and Carex acuta), expanding stinging nettle (Urtica dioica) and reed canary grass Phalaris arundinacea. (Dušek et al. [4]).

\section{Methods}

Digital elevation model (DEM) of the terrain has been elaborated from aerial spectrofotogrammetric images, made at possible lowest water level out of vegetation period (to minimize the ground cover by leaves). The accuracy of the model is $10 \mathrm{~cm}$. Scenario A represents state as it is while scenario B represents virtual transformed state (Fig. 1) for what river bed was straightened, being positioned at the original elevation, and floodplain terrain was flattened, and land use changed into arable land (wheat production).

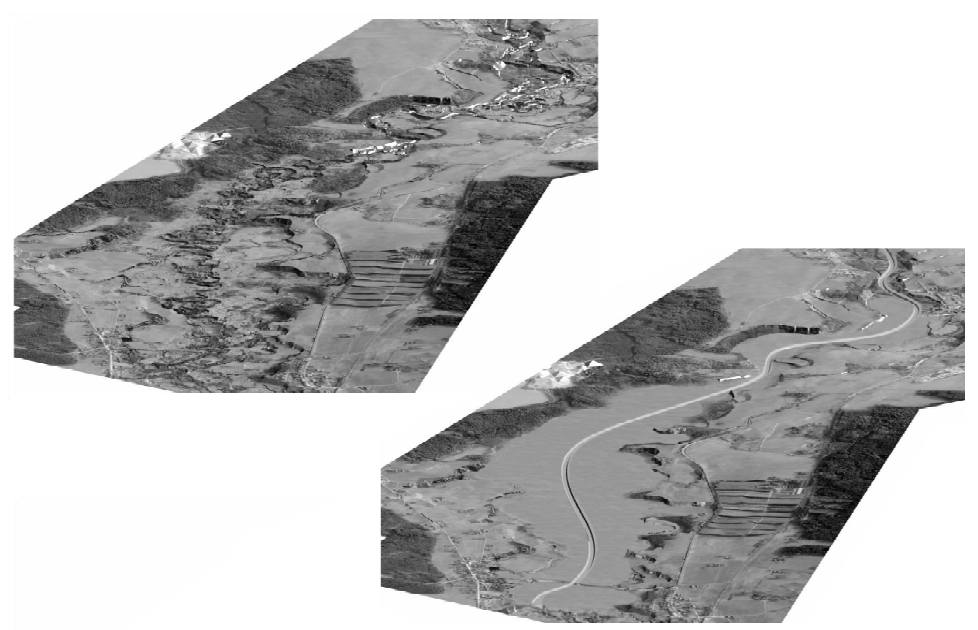

Figure 1: $\quad$ Aerial view of the scenario A (above) and scenario B (bottom).

Flood mitigation was estimated by flood flow model FAST 2D. This twodimensional depth-averaged numerical model enables to simulate free surface water flow in open channels and inundation areas with complex geometry in the course of various hydrological events (Wenka et al. [5]). It is suitable for modeling of natural rivers as well for the detailed modeling of highly urbanized floodplain areas and the estimation of anthropogenic impacts on the flood flow 
conditions (Valenta and Valentová [6]). Computation is based on depth-averaged Reynolds equations and k-epsilon turbulence model and uses the control volume method with curvilinear non-orthogonal computational grid.

Model input consists of geometrical data of the computational grid, terrain topography (DEM) and definition of flow obstacles (buildings, roads etc.), bottom shear stress parameters and boundary conditions. Primary model output provides data fields with depth-averaged velocity vectors, water elevation values and turbulence specific for particular computational cells. Flood wave transformation was modelled with simple integration in time using the balance equation for the inflow discharge, outflow discharge and retention volume variables.

For monetary evaluation, the "replacement cost" method was used (Champ et al. [7]), assuming the local water management intend to increase water retention by artificial constructions only. The average cost of one cubic meter water retention in the man-made construction in the Czech Republic was multiplied by effective retention volume above one inundated hectare of the floodplain and divided by discount rate. For scenario $\mathrm{B}$, the value was lowered by factor, estimated from comparing flood wave mitigation effect in A and B, modelled by FAST 2D flow model.

Carbon sequestration was calculated by annual measurement of $\mathrm{CO}_{2}$ fluxes between wetland ecosystem and atmosphere (Dušek et al. [4]). Eddy covariance measurements of $\mathrm{CO}_{2}$ concentration, water vapor, wind speed and air temperature (InSituFlux) were performed with a Licor 7500 open path infrared gas analyzer (LI-COR) and ultrasonic anemometer R3 (GILL Instruments Limited). Licor and anemometer were installed at $2.7 \mathrm{~m}$ above the surface to integrate fluxes from the area of $1200 \mathrm{~m}^{2}$. The FLUXNET methodology was applied to the data processing. The sequestered carbon was converted to tons of $\mathrm{CO}_{2} \cdot \mathrm{ha}^{-1} \cdot \mathrm{m}^{-1}$ and multiplied by marketable price of emission limits in 2008 .

All major biotopes were identified and their contribution to the biodiversity value of total area of the study site was calculated. Each biotope was given a value in points according to Seják and Dejmal [8]. This country specific value reflects the criteria like maturity, structural and species diversity, biotope and rareness, anthropogenic impact, and vulnerability. The higher the point value is, the more valuable, from ecological point of view, the biotope is. For monetary evaluation, point value (per unit of area) is calculated from the average cost of accomplished revitalization projects, which increases point value of the area by creation of more valuable biotopes. Hence, the point value reflects the ability and willingness of the society to pay for biodiversity increase. Average point value per ha of the floodplain was divided by 20 for discount rate.

For fish production estimate, the data from the Czech Fishery Union, which monitors the fish catches made by sport anglers, were obtained. The study area is a designated angling territory so we could relate the catches directly to its extent. For monetary evaluation, local market prices of fish were used.

The hay, timber and wheat production data and prices were obtained from local farmers, areas of meadows, forest and virtual arable land were calculated by GIS. 
All services were calculated for the whole area and then related to one hectare of the floodplain to be comparable and added together.

\section{Results}

\subsection{Flood mitigation}

According the DEM of the study site, the potential retention volume of the whole preserved floodplain is 7 mil. $\mathrm{m}^{3}$ on the area of 478 ha (Pithart et al. [9]). The transformation effect on the flood wave was modeled on the shorter, $5 \mathrm{~km}$ long floodplain segment at scenarios $A$ and B. For the input flood wave $Q_{100}$, the effective retention volume was $2.3 \mathrm{mil} . \mathrm{m}^{3}$ and for $\mathrm{B} 0.83 \mathrm{mil} . \mathrm{m}^{3}$ on the area of 283.5 ha. This indicates the decrease to $36 \%$ at the transformed floodplain (B). The lower input flood wave, the higher difference between the scenarios A and B in culmination time shift and reduction of peak discharge was modeled (Tab.1). Making a multi-fold gradual flood wave regression from $\mathrm{Q}_{100}$ to $\mathrm{Q}_{50}$, we were able to calculate the length of the floodplain segment necessary for such a transformation. This was $28.9 \mathrm{~km}$ for scenario A and $66.6 \mathrm{~km}$ for scenario B. Hence, the mitigation effect for this particular flood wave transformation was more then double at near-natural state (A) if compared to transformed floodplain (B).

The average cost of one cubic meter of artificial water retention is 16.05 EUR in the Czech Republic. This (divided by 20 for $5 \%$ discount rate) gives the value of $6511 \mathrm{EUR} \mathrm{ha}^{-1} \cdot \mathrm{yr}^{-1}$ for scenario A. For scenario B, the value was lowered to $2349.5 \mathrm{EUR} \mathrm{ha}^{-1} \cdot \mathrm{yr}^{-1}$ (36\% of A).

Table 1: Culmination time shift and peak discharge ration at scenario $\mathrm{A}$ (state as it is) and B (transformed floodplain). Values for input flood wave with 5, 20 and 100 year returned period.

\begin{tabular}{|c|c|c|c|c||c|c|}
\hline \multirow{4}{*}{ Scenario } & \multicolumn{2}{|c|}{$\begin{array}{c}\text { Input flood wave } \\
\mathbf{Q}_{\mathbf{5}}\end{array}$} & \multicolumn{2}{c|}{$\mathbf{Q}_{\mathbf{2 0}}$} & \multicolumn{2}{|c|}{$\mathbf{Q}_{\mathbf{1 0 0}}$} \\
\cline { 2 - 7 } & $\begin{array}{c}\text { Culmination } \\
\text { time shift }\end{array}$ & $\begin{array}{c}\text { Peak } \\
\text { discharge } \\
\text { ratio }\end{array}$ & \multicolumn{2}{|c|}{} & \multicolumn{2}{|c|}{} \\
\hline $\mathrm{A}$ & $7.5 \mathrm{~h}$ & $90.4 \%$ & $6.5 \mathrm{~h}$ & $91.7 \%$ & $5.5 \mathrm{~h}$ & $93.2 \%$ \\
\hline \hline $\mathrm{B}$ & $0.0 \mathrm{~h}$ & $100 \%$ & $3.5 \mathrm{~h}$ & $95.9 \%$ & $3.5 \mathrm{~h}$ & $94.7 \%$ \\
\hline
\end{tabular}

\subsection{Carbon sequestration}

Sedge grass stand in the studied wet meadows accumulated about $1988 \mathrm{~kg} \mathrm{C}$ ha $^{-1}$ in 2006 and $2202 \mathrm{~kg} \mathrm{C} \mathrm{ha}^{-1}$ in 2007 (Dušek et al. [4]). Net ecosystem production (NEP) reflected different hydrological situations (Fig.3): the summer 

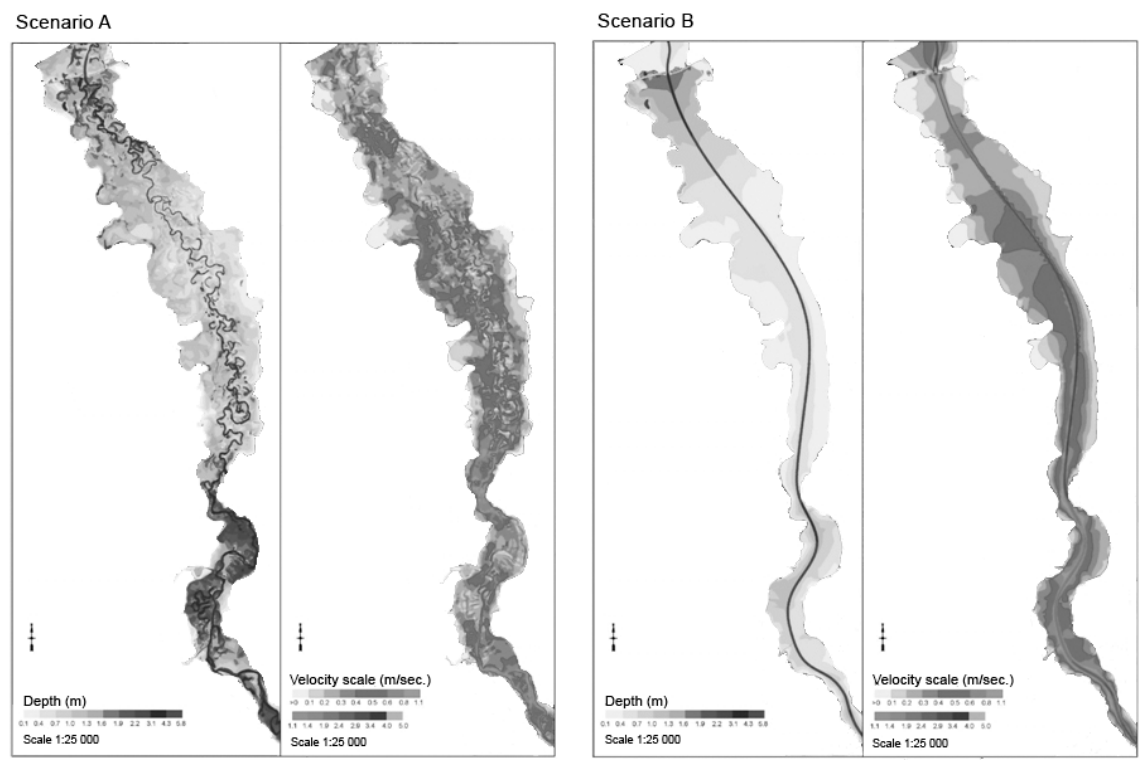

Figure 2: $\quad$ Output from FAST 2D model for simulation of $\mathrm{Q}_{100}$ flood wave at scenarios A (two diagrams on the left) and B (right). Left parts of the diagrams show depth distributions (scale in $\mathrm{m}$ ); right parts show flow velocity in $\mathrm{m} \cdot \mathrm{s}^{-1}$.

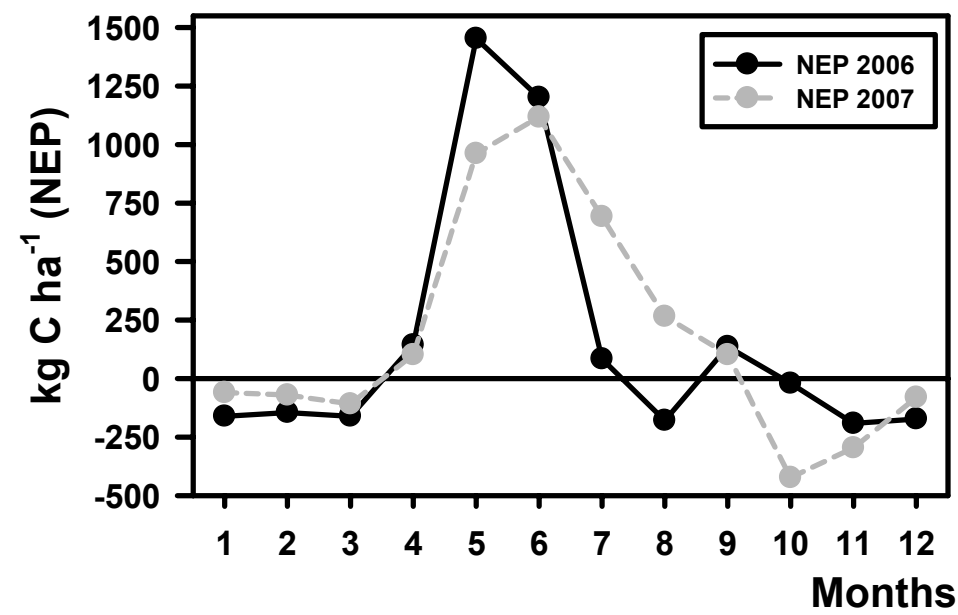

Figure 3: Net ecosystem production during the two consequent seasons at the floodplain fen. Positive values represent carbon sequestration, associated with vegetation period. 
flood in 2006 decreased carbon assimilation in August. The rate of carbon accumulation was also measured directly by harvesting aboveground plant biomass. Maximum biomass, which was reached in the 2006 and 2007 growth season, was $3520 \mathrm{~kg} \cdot \mathrm{ha}^{-1}$ and $4330 \mathrm{~kg} \cdot \mathrm{ha}^{-1}$ respectively. The amount of carbon in harvested biomass (approximately $45 \%$ from the dry mass) corresponded with eddy covariance measurements, being lower for heterotrophy respiration (included only in eddy-covariance method) and methanogenesis (not measured).

The area where the fluxes were measured was taken as a representative for all wetland and grass ecosystems in the floodplain. For floodplain forest, NEP was not measured, but should not be lower in principle, because the forest is partly young, overgrowing former pastures. For this study, it was taken as equal to wetland. For aquatic ecosystems NEP was estimated as zero, because the erosion and deposition of sediment particles is roughly in balance in such a type of floodplain. These assumptions probably cause the underestimation of carbon sequestration.

At Wet Meadows site, $2.095 \mathrm{t}$ of $\mathrm{C} \cdot \mathrm{ha}^{-1} \cdot \mathrm{yr}^{-1}$ was sequestered in average, which is $7.54 \mathrm{t}$ of $\mathrm{CO}_{2}$. The marketable price of $1 \mathrm{t}$ of emission limit was 18.4 EUR. $\mathrm{t}^{-1}$ in 2008, what gives the value of 138.7 EUR.ha ${ }^{-1} \cdot \mathrm{yr}^{-1}$ for this service.

For scenario B we estimated the carbon sequestration as zero. Permanently drained wetland soils are even the sources of $\mathrm{CO}_{2}$, because the organic matter, being reduced in waterlogged soil layers, is oxidised by atmospheric oxygen (Mitch and Gosselink [10]). For proper carbon balance, it would be necessary to measure also the transport of dissolved carbon by river water.

\subsection{Biodiversity}

Following biotopes with their point values have been identified and mapped within the study site. Their contribution to the total area is in brackets.

Scenario A:

- Bream zone of running water $62(3 \%)$

- Macrophyte vegetation of shallow standing waters $53(1 \%)$

- Wetland willow carrs $36(15 \%)$

- Hardwood alluvial forest (bottomland hardwoods) 66 (13\%)

- Softwood alluvial forest (bottomland softwood) 65 (5\%)

- Solitary trees 25 (1\%)

- Riparian beds of reed canary grass $28(30 \%)$

- Alluvial foxtail meadows $46(15 \%)$

- Vegetation of tall sedges $26(10 \%)$

- Arable land $10(8 \%)$

-

Scenario B:

- Bream zone of running water $62(3 \%)$

- Arable land $10(97 \%)$

Average point value per ha corrected for area contribution is 38 points for scenario A and 12 points for scenario B respectively. Financial value of one point is 5583 EUR.ha $^{-1}$ in the Czech Republic, what gives (at 5\% discount rate) 
10468 EUR.ha ${ }^{-1} \cdot \mathrm{yr}^{-1}$ for scenario A and 3350 EUR.ha ${ }^{-1} \cdot \mathrm{yr}^{-1}$ for scenario B (decrease to $32 \%$ of $\mathrm{A}$ ).

\subsection{Production of hay, timber, fish and wheat}

The average regional hay harvest $0.2 \mathrm{t}^{\mathrm{ha}} \mathrm{ha}^{-1}$ gives the production of $365.8 \mathrm{t}$ on the area of 183 ha. Total annual benefit is 25529 EUR at the price 70 EUR per t, so the income per ha of the floodplain is 54 EUR.

Timber production was estimated as $5 \mathrm{~m}^{3} \cdot \mathrm{ha}^{-1} \cdot \mathrm{yr}^{-1}$. At the average price 23 EUR per $\mathrm{m}^{3}$ and 61 ha of the floodplain forest area this gives $15 \mathrm{EUR}$. $\mathrm{ha}^{-1} \cdot \mathrm{yr}^{-1}$.

Fish catches in $\mathrm{kg}$ according species and their market prices per $\mathrm{kg}$ ( Tab. 2) provided data for calculation of the total amount of catches (12 161 EUR), what gives the value 26 EUR per ha of the floodplain. For scenario B we estimate this benefit to be reduced to $50 \%$, because the pike looses its natural habitats for reproduction and also carp looses the relatively still parts of river stream.

Table 2: $\quad$ Fish catches at Angling Area Lužnice, code 421043. Source: Czech Anglers Union. Source for prices: regional commercial sale of live fish in 2008.

\begin{tabular}{|c|c|c|c|}
\hline Species & Kg & price per kg & price in total \\
\hline Carp & 2466 & 2.1 EUR & 5367 EUR \\
\hline Pike & 790 & 8.4 & 6616 \\
\hline Bream & 115 & 1.19 & 134 \\
\hline Others & 94 & 4.7 & 44 \\
\hline In total & 3465 & & $\mathbf{1 2} \mathbf{1 6 1}$ \\
\hline
\end{tabular}

Table 3: Estimation of monetary value of ecosystem services per hectare for Scenario A and B of the Lužnice floodplain segment. Services which were not evaluated quantitatively are at least commented.

\begin{tabular}{|c|c|c|}
\hline Service & \multicolumn{2}{|c|}{ Value per ha in EUR } \\
\hline & Scenario A & Scenario B \\
\hline Flood wave mitigation & 6511 & 2350 \\
\hline Biodiversity refuge & 10468 & 3350 \\
\hline Carbon sequestration & 139 & 0 \\
\hline Fish production & 26 & 18 \\
\hline Hay production & 54 & 0 \\
\hline Wood production & 15 & 0 \\
\hline Wheat production & 0 & 541 \\
\hline Nutrient retention & Positive & Negative \\
\hline Groundwater recharge & Higher & Lower \\
\hline Sediment retention & Positive & Negative \\
\hline Recreation & Positive & Lower or zero \\
\hline Total & $\mathbf{1 7 2 1 3}$ & $\mathbf{6 ~ 2 5 9}$ \\
\hline
\end{tabular}


Wheat production was derived from the average harvest rate per hectare in the Czech Republic (5.1 t, Czech Statistical Office) and its market price (111.1 EUR. $t^{-1}$, Czech Industrial Mills Union). The wheat price makes 541 EUR per ha of the floodplain. No damage costs caused by flood are included.

\subsection{Overview of ecosystem services}

Biodiversity refugium and flood mitigation are in one or two order of magnitude higher than other services (Table 3). Note the services are related to hectare of a floodplain (inundated area bordered with river terraces). The overall value of all services reached $17213 \mathrm{EUR} \mathrm{ha}^{-1} \mathrm{yr}^{-1}$ for scenario A, and $6259 \mathrm{EUR} \mathrm{ha}^{-1} \mathrm{yr}^{-1}$ for scenario $B$, respectively, which indicates a decrease of $64 \%$ of the value of $A$.

\section{Conclusion and discussion}

The results of this study show the near-nature state of the floodplain segment provides number of valuable ecosystem services. This is in agreement with Costanza et al. [11] who found river floodplains at second position among the world ecosystems, if their services are related per unit area. Their average global value they estimated as 14880 EUR.ha $^{-1} \mathrm{yr}^{-1}$ in 1997, which is quite comparable with our results. For this reason, it is quite important, how the management of floodplains will look like and what land use will prevail. This study shows the typical floodplain transformation leads to overall decrease of its value, here for $64 \%$. This decrease is probably much higher, because not all ecosystem services were taken into this analysis, basically because the data were not available, and also we always preferred underestimates when we were in doubt. The setting of scenario B is quite arbitrary of course; we can imagine other typical scenarios. For instance, replacing wheat with hay production would decrease the price of commodity but the system would be better adapted to flooding, which will result in smaller damages by flood, and higher sediment and nutrients retention (in the case of wise manuring). On the other hand, the river can be restricted by levees which would decrease its retention capacity drastically, and new land for settlement could be at disposal. To calculate the new balances would require the land, property and insurance evaluation. In no doubt, for any floodplain development and decision making process the ecosystem services analysis may become quite useful information source.

\section{Acknowledgements}

The study was supported by project 'Water retention in floodplains and measures of its increase' (No. QH82078) funded by Ministry of Agriculture of Czech Republic. 


\section{References}

[1] Plán hlavnich povodi České republiky (Plan of Main Watersheds of Czech Republic), Ministerstvo zemědělství ČR (Czech Ministry of Agriculture), Prague, 2006.

[2] Turner, R.K., Georgiou, S. \& Fisher, B., Valuing ecosystem services: the case of multi-functional wetlands. Cromwell Press, Towbridge, UK, 2008.

[3] Pithart, D., Pichlová, R., Bílý, M., Hrbáček, J., Novotná, K. \& Pechar, L., Spatial and temporal diversity of small shallow waters in river Lužnice floodplain. Hydrobiologia. 584 265-275. 978-4020-6398-5, 2007.

[4] Dušek, J., Č́žková, H. \& Czerný, R, Influence of summer flood on the net ecosystem exchange of $\mathrm{CO}_{2}$ in a temperate sedge-grass marsh. Agricultural and Forest Meteorology, 149(9), pp. 1524-1530, 2009.

[5] Wenka, T., Valenta, P. \& Rodi, W., Depth averaged calculation of flood flows in a river with irregular geometry. Proc. of the XXIV. IAHR Congress, Madrid, pp. A-225 - A-232, 1991.

[6] Valenta, P. \& Valentová, J., Detailed Numerical Modeling of Flood Flow in Floodplains with Complex Geometry. Acta Polytechnica 3(43), pp. 55 - 60, ISSN 1210-2709, 2003.

[7] Champ, P., Boyle, K.J. \& Brown, T.C. (eds), A Primer on Nonmarket valuation. Kluwer Academic Publisher: Dordrecht, The Netherlands, 2003.

[8] Seják J. \& Dejmal I., Hodnocení a oceňování biotopů České Republiky (Evaluation of Biotopes in The Czech Republic). Czech Ecological Institute: Prague, pp.422, 2003.

[9] Pithart, D., Křováková, K. \& Žaloudík, J., Case study: Ecosystem services of a floodplain with a preserved hydrological regime, Czech Republic. The role of environmental management and eco-engineering in disaster risk reduction and climate change adaptation, eds. Saalismaa N. et al., ProAct Network: Tannay, Switzerland, pp. 34-36, 2008.

[10] Mitsch, W.J. \& Gosselink, J.G., Wetlands. John Willey \& Sons, Inc., New York, 2000.

[11] Costanza, R., d'Arge, R, de Groot, R., Farber, S., Grasso, M., Hannon, B., Limburg, K., Naeem, S., O’Neill, R.V., Paruelo, J., Raskin, R.G., Sutto, P., $\&$ Belt van der, M., The value of the world's ecosystem services and natural capital. Nature 387:253-260, 1997. 